Alla A. VORONEZHCEVA,

Senior Lecturer in Pre-university Training Department, Odessa State Environmental University;

15 Lvovskaya str., Odessa, 65016, Ukraine; tel.: +38 0671990164; e-mail: allarkvoronezh@gmail.com;

ORCID ID: 0000-0002-8458-4677

Olga V. CHERNAYA,

PhD (Pedagogy), Senior Lecturer in Pre-university Training Department, Odessa State Environmental University;

15 Lvovskaya str., Odessa, 65016, Ukraine; tel.: +38 0677399662; e-mail: blackolga1709@gmail.com;

ORCID ID: 0000-0003-1411-4984

\title{
STRUCTURAL COMPONENTS OF SOCIOPRAGMATIC COMPETENCE OF FOREIGN STUDENTS
}

Summary. The purpose of the article is to systematize the factors influencing the success of foreign students as subjects of cultural interaction. The object of the studying is the components of socio-pragmatic competence. The subject of the studying is the criteria of appreciation the formation of the components of sociopragmatic competence of foreign students who learn Russian and Ukrainian languages as languages for obtaining professional knowledge. As a result of the work carried out, the following structural components of sociopragmatic competence of foreign students are identified and presented: cognitive, affective, and subject-practical. The paper concludes that the criteria for the cognitive component are knowledge of the principals of intercultural social interaction and etiquette and rules of conduct in the country of education; the criteria for the formation of the affective component are tolerance, empathy, and sociocultural attentiveness; as a criterion for appreciation of the subject-practical component, the ability to interpret social and cultural phenomena, as well as the ability to ensure personal security and achieve their object with their actions, has been put forward.

Key words: foreign student, sociopragmatic competence, cognitive component, affective component, subject-practical component, tolerance, sociocultural attentiveness, sociopragmatic failures.

Статтю отримано 30.10.2019 р.

http://dx.doi.org/10.18524/2307-4558.2019.32.187762

УДК $811.161 .1 / .2 ’ 243: 378: 347.176 .2$

МоЙСЕЄНКо Наталія Григорівна,

кандидат філологічних наук, доцент кафедри граматики англійської мови Одеського національного університету імені I. I. Мечникова; Французький бульвар, 24/26, м. Одеса, 65058, Україна; тел.: +38 0671087618 ; e-mail: natalymoiswx@gmail.com; ORCID ID: 0000-0002-8465-5519

\section{СІЗОВА Любов Володимирівна,}

старший викладач кафедри мовної та загальногуманітарної підготовки іноземців Одеського національного університету імені I. I. Мечникова; пров. Маяковського, 7, м. Одеса, 65082, Україна; тел:.+38 0671682265 ; e-mail: natalymoiswx@gmail.com; ORCID ID: 0000-0002-4849-5044

\section{САМОСТІЙНА РОБОТА СТУДЕНТІВ У ПРОЦЕСІ ВИКЛАДАННЯ ДІЛОВОӦ УКРАЇНСЬКОЇ ТА РОСІЙСЬКОЇ МОВ ЯК ІНОЗЕМНИХ СТУДЕНТАМ ГУМАНІТАРНИХ СПЕЦІАЛЬНОСТЕЙ}

Анотація. Об'єктом описаного дослідження є результати спостережень за виконанням самостійної роботи студентами 3-4 курсів гуманітарних спеціальностей у процесі вивчення ними ділової української та російської мов як іноземних. Предмет цього дослідження - особливості організації самостійної роботи у процесі викладання ділової української та російської мов як іноземних студентам 3-4 курсів гуманітарних спеціальностей. Мета: дослідження націлене на аналіз досвіду щодо зазначеного вище питання та визначення алгоритму організації та контролю самостійної роботи під час навчання ділової української та російської мов іноземним студентам. Методологія: у дослідженні застосовувалися методи анкетування, спостереження, зіставлення, синтезу та аналізу, описовий метод. У результаті проведеної дослідницької роботи складено алгоритм самостійної роботи для курсу ділової української та російської мов як іноземних для студентів гуманітарних спеціальностей. Висновки. Самостійна робота студентів у процесі вивчення ділової української та російської мов як іноземних дає можливість оптимізувати, інтенсифікувати процес навчання та сформувати у студентів навички креативної діяльності. Самостійна робота має розглядатись не як другорядний додаток у процесі навчання та виховання, а як його невід'ємна частина. Ця робота має охоплювати не менш $1 / 3$ кількості годин, відведених на вивчення одного модуля. Дуже важливою рисою самостійної роботи має бути її звязок із активною та практичною діяльністю. Виконуючи завдання самостійної роботи, потрібно застосовувати технічні засоби, аудіо та відео системи презентації матеріалу, Інтернет.

Ключові слова: ділова мова, креативна діяльність, самостійна робота, продуктивна діяльність, компетентність, українська і російська мови. 
Постановка ппроблеми. Курс української та російської мови як іноземної включає такий тематичний підрозділ як “Ділова мова). Беручи до уваги сучасний компетентністний підхід до навчання іноземних мов, виникає потреба вдосконалювати процес викладання зазначеної дисципліни [4].

Зазвичай програма з ділової української та російської мов містить достатньо широкий спектр тем: розмова по телефону, ділове листування, знайомство, переговори, презентація, імпорт і експорт, контракти, організація компанії, реклама, відрядження, відвідуванння виробничого підприємства, спілкування в офрісі, готель. Якщо співставити тематичний обсяг із кількістю аудиторних годин (зазвичай їх обсяг складає від 20 до 40 за семестр), то, враховуючи зміст комунікативної компетенції, який включає готовність та спроможність до іншомовної мовленнєвої взаємодії [4], окреслюється потреба в організації роботи з вивчення зазначеної дисципліни таким чином, щоб його наслідком була спроможність іноземного студента вільно реагувати в певній мовленнєвій ситуації, вирішувати конфолікти, висловлювати свою думку, вести певну професійну активність. Для цього студент має одержати лінгвістичні, соціолінгвістичні, комунікативні знання і уміння, якими за 20-40 аудиторних годин оволодіти неможливо. Для вирішення зазначеної проблеми ми зробили спробу залучити студентів до самостійної роботи, організованої таким чином, щоб вона сприяла засвоєнню матеріалу, потрібного для формування навичок ділового спілкування. Активізація цього матеріалу та вихід в усну та письмову комунікацію були відпрацьовані під час аудиторних занять. У цій статті наведено результати нашого дослідження.

Зв’язок із попередніми дослідженнями. Роль самостійної роботи у навчанні, її види та методи аналізувала ціла низка науковців, у їхніх дослідженнях підкреслено неабияке значення цього виду навчальної діяльності для формування необхідних навичок і умінь $[1-3 ; 5 ; 6 ; 9 ; 10]$. Видатний дослідник у сфері педагогіки Ян Амос Коменський зазначав: “Нехай керівною основою нашої дидактики буде дослідження та відкриття методу, при якому учнів менше б навчали, але щоб вони у той же час більше б навчались самі» [5, с. 243]. Щодо методів застосування самостійної роботи під час навчання іноземних мов, то вони є актуальним аспектом сучасної педагогічної науки. Науковці по-різному підходять до визначення видів самостійної роботи та їх систематизації, вони також порізному оцінюють значення та роль певних форм самостійної роботи $[2 ; 3 ; 6 ; 9 ; 10]$. Треба також зазначити, що конкретні умови та цілі певного навчального процесу диктують необхідність своєї інтерпретації та адаптації існуючих теоретичних положень у процесі їх впровадженні в практику.

Формулювання завдань дослідження. Наше дослідження націлене на аналіз досвіду щодо розв'язання проблеми оптимізації самостійної роботи студентів-гуманітаріїв у процесі вивчення ними ділової української та російської мов як іноземних та визначення алгоритму організації та контролю такої роботи. Отже, об'єктом описаного у статті дослідження є результати спостережень за виконанням самостійної роботи студентами 3-4 курсів гуманітарних спеціальностей у процесі вивчення ними ділової української та російської мов як іноземних. Предмет цього дослідження особливості організації самостійної роботи в цьому процесі. У дослідженні застосовувалися методи анкетування, спостереження, зіставлення, синтезу та аналізу, описовий метод.

Виклад основного матеріалу. Насамперед, визначимо поняття (самостійна робота». Сучасні науковці трактують його по-різному $[1-3 ; 5 ; 6 ; 9 ; 10]$. Так, у зарубіжній педагогічній літературі для позначення самостійної роботи використовується низка термінів, що підкреслюють різні аспекти самостійної роботи. Наприклад, у Німеччині використовують словосполучення “опосередковане навчання), яке позначає, що робота проводиться без прямого втручання викладача. У педагогічній літературі Австрії та Швейцарії вживається термін (тиха робота), який припускає наявність тиші й усамотненості, що супроводжують самостійну роботу. У фрранцузькій та англійській літературі зустрічається термін (індивідуальна робота), в США введено термін (незалежне навчання», коли студентам пропонують виконання обов'язкових програм, однак залишають відносну свободу у виборі матеріалів та засобів засвоєння [10, с. 7-8].

У вітчизняній педагогічній літературі в самостійній роботі зазначають їі три суттєві ознаки: вона спланована та виконується, по-перше, за завданням викладача, по-друге, при його методичному керівництві, по-третє, без викладацької безпосередньої участі [1-3; 6; 10$]$.

Щодо задач самостійної роботи В. В. Горлинський вважає, що основні дидактичні цілі самостійної роботи можна зводити до:

1) розвитку навичок самостійного одержання знань із різних джерел;

2) сприяння формуванню навичок та вмінь, що є необхідними для майбутніх спеціалістів;

3) підвищення відповідальності слухачів за свою професійну підготовку, формування особистісних і професійно-ділових якостей;

4) формування у студентів професійного мислення на основі самостійної роботи й учбових дисциплін [1].

Аналізуючи зазначені вище положення, можна виокремити такі суттєві напрями самостійної навчальної діяльності студента:

1. Студент має виконувати роботу сам, без посередньої участі викладача.

2. Студент має бути здатним на самостійні мисленнєві операції, він має самостійно зорієнтуватися в заданому матеріалі. 
3. Виконання роботи строго не регламентовано, студент може самостійно обирати зміст і засоби виконання завдання.

Стосовно задач самостійної роботи в процесі вивчення ділової української та російської мов іноземцями ми вважаємо за доцільне звернути увагу на розвиток і формування навичок і умінь сприйняття й використання інформації, на формування мовної та мовленнєвої компетенцій, студент має навчитися одержувати знання, потрібні для ділової комунікації, а також застосовувати їх у діловому спілкуванні. Такий вид роботи має сприяти формуванню самостійності як риси особистості студента, а також його самоосвітній компетенції.

Щодо самого поняття (самостійна робота) у процесі вивчення ділової української та російської мови іноземцями, то ми розуміємо його як діяльність студента без участі викладача. Самостійною в цьому сенсі є діяльність, якою студент займається згідно із внутрішніми інтенціями, коли він самостійно знаходить мету та засоби діяльності. Тут важливим є те, що студенти мають самостійно думати та вирішувати проблеми, причому немає значення, чи така робота проводиться у фронтальній, чи в індивідуальній формі. Самостійна робота вважається можливою та необхідною під час лекцій $[10$, c. 7]. Як специфічна форма навчально-виховного процесу самостійна робота у процесі вивчення ділової української та російської мов іноземцями є необхідною, бо виконує наступні функції:

- навчальну (систематизація та закріплення знань студентів);

- розвивальну (розвиток пізнавальних можливостей студентів, їх уваги, пам'яті, мислення, мовлення);

- виховну (виховання стійких мотивів учбової діяльності, навичок культури розумової праці, самоорганізації та самоконтролю, особистісних якостей: чесності, любові до праці, вимогливості до себе, самостійності тощо).

Самостійна робота $\epsilon$ також запорукою формування навичок продуктивної діяльності студентів. Зазначимо, що у своїх дослідженнях педагоги та психологи виокремлюють чотири рівні продуктивної діяльності студентів, що відповідають їх учбовим можливостям:

1) дії студентів, що копіюють певний приклад;

2) репродуктивна діяльність щодо відтворення інформації про різні якості об'єкта вивчення; ця діяльність, здебільшого, не виходить за межі пам'яті;

3) продуктивна діяльність самостійного застосування отриманих знань, що виходять за межі відомого зразка; вона потребує здібностей до дедуктивного й індуктивного методів;

4) самостійна діяльність із переносу знань у вирішенні задач в абсолютно нових ситуаціях, умовах складанню програм до прийняття рішень, формування гіпотетичного аналогового мислення.

Ідеальним результатом навчання вважається такий рівень розвитку пізнавальної діяльності студентів, коли вони можуть самостійно ставити завдання, знаходити шляхи його вирішення, контролювати й оцінювати результати своєї пізнавальної діяльності, а потім формулювати наступні задачі, тобто коли студенти засвоюють усі компоненти раціонально організованої структури пізнавальної діяльності, характерної для самоосвіти. Отже, як бачимо, самостійна робота є необхідною умовою виконання дій, характерних для кожного рівня. Кінцевим етапом пізнавальної діяльності є творча самостійна діяльність.

Щодо ролі викладацького контролю, ми дійшли висновку, що на всіх етапах виконання самостійної роботи студентом вона повинна контролюватися викладачем, аби студент бачив перехід своїх знань на більш високий рівень, навчався самооцінці результатів своєї роботи i, спираючись на ці оцінки, планувати подальшу роботу. Так, А. С. Границька пропонує контрольний комплекс, який забезпечує повну контрольованість результатів самостійної роботи. У такий комплекс включають деякі види контролю: контроль викладача, самоконтроль, взаємоконтроль, внутрішній самоконтроль [2, с. 10].

Кінцевий етап контрольного комплексу — це внутрішній самоконтроль. Перехід до внутрішнього самоконтролю означає, що правильні учбові дії сформовані і потреба в зовнішньому контролі відпадає. Оскільки, на наш погляд, студент, з об'єктивних причин, не може адекватно оцінити себе, порада і оцінка викладача мають бути присутніми на кожному етапі роботи, а об'єм контролю за процесом виконання роботи можна обмежити.

Таким чином, аналіз наукових робіт щодо проблеми організації самостійної роботи студентів і наш власний досвід викладання ділової української та російської мов як іноземних дають змогу зробити наступні висновки:

1. У теоретичних джерелах самостійна робота студентів з іноземних мов не визначається як базовий вид роботи, що на практиці, в деяких випадках, призводить до нехтування цим видом пізнавальної діяльності або до відведення самостійній роботі другорядної ролі. Такі підходи негативно впливають на процес формування пізнавальних і продуктивних навичок студента, а також обмежують загальний обсяг знань, отриманих студентом. На наш погляд, самостійна робота має бути обов'язковою часткою учбового процесу, вона має знаходити часове відображення у робочих програмах і має бути ретельно спланована викладачем.

2. У визначенні видів самостійної роботи з іноземної мови сьогодні мало враховують фактор ступеню оволодіння студентом основами професійної діяльності. Це зумовлює змістовну асиметрію між матеріалом з ділової мови та системою понять, що склалась у процесі оволодіння базовими дисциплінами. Виходячи з цього положення, викладач іноземної мови має працювати в тісному контакті 
із фахівцями основних дисциплін, які має вивчити студент, складати завдання та навчально-методичні посібники для конкретної спеціальності / спеціалізації. Окрім теоретичного та практичного матеріалу, в посібниках мають подаватися творчі завдання, виконання яких передбачене під час самостійної роботи, що охоплюватиме не менш 1/3 часу, відведеного на вивчення дисципліни.

3. У пізнавальній діяльності студентів не враховується провідна роль сприйняття в процесі оволодіння мовним матеріалом, хоча дані педагогічної психології свідчать про те, що активний вхід інформації у значній мірі компенсує механічне тренування. Беручи до уваги цей факт, у наших навчально-методичних посібниках ми презентуємо новий матеріал на основі активного входу інформації. На 3-4 курсах ефективним видом роботи із засвоєння нового матеріалу є ділові ігри, проводити які ми рекомендуємо на кожному занятті з ділової мови.

4. У самостійній роботі студента недостатньо використовуються різні види та рівні пізнавальної діяльності: активний свідомий і підсвідомий. Ми вирішуємо цю проблему завдяки аудіо-відео засобам навчання, а також шляхом долучення студентів до активної діяльності в певному підрозділі навчального закладу, у процесі підготовці до різних наукових і громадських заходів.

5. Недостатньо широко використовують технічні засоби навчання. Беручи до уваги цю проблему, рекомендуємо в навчальному процесі більш активно використовувати систему аудіо та відео презентації матеріалу, Інтернет.

6. Самостійна робота студентів у процесі вивчення ділової української та російської мов як іноземних дає можливість оптимізувати, інтенсифбікувати процес навчання та сформувати у студентів навички креативної діяльності. Позааудиторна самостійна робота має розглядатись не як другорядний додаток у навчально-виховному процесі, а як його невід'ємна частина. Дуже важливою рисою самостійної роботи має бути її зв'язок із активною та практичною діяльністю.

\section{Лimература}

1. Горлинський В. В. Духовні координати безпеки суспільства. Стратегічна панорама. Київ : Нац. ін-т стратегічних досліджень, 2006. № 1. URL : http://www.niisp.gov.ua/vydanna/panorama/issue.php?s $=$ prnb1\&issue $=200$

2. Границкая А. С. Научить думать и действовать : адаптивная система обучения в школе. Москва: Просвещение, $1991.175 \mathrm{c}$

3. Есипов Б. П. Самостоятельная работа учащихся на уроках. Москва : Высш. шк., 1991. 315 с.

4. Загальноєвропейські рекомендації з мовної освіти : вивчення, викладання, оцінювання. Київ : Ленвіт, 2003.125 с.

5. Коменский Я. А. Избранные педагогические сочинения : в 2 т. Москва : Педагогика, 1982. Т. 1. 320 с.

6. Конышева А. В. Групповой метод обучения при организации самостоятельной работы студентов по методике. Новые технологии в современном процессе обуиения. Новополоцк : ПГУ, 2003. С. 324-329.

7. Лурия А. Р. Внимание и память. Москва : Изд-во МГУ, 1975. 268 с.

8. Мойсеєнко Н. Г., Сізова Л. В. Ділова мова : навчально-методичний посібник. Одеса : ОНУ, 2019. 123 с.

9. Нильсон О. А. Исследование роли самостоятельной работы учащихся в учебном процессе. Таллин : Валгус, 1986. 302 c.

10. Онучак Л. В. Педагогічні умови організації самостійної позааудиторної роботи студентів економічних спеціальностей : автореф. дис. ... канд. пед. наук : 13.00.04. Київ, 2002. 18 с.

\section{References}

1. Gorlynskyi, V. V. (2006), "Spiritual coordinates of the security of society», Strategic panorama [“Dukhovni koordynaty bezpeky suspilstva», Stratehichna panorama], National Institute for Strategic Studies, Kyiv, vol. 1, available at: http://www.niisp.gov.ua/vydanna/panorama/issue.php?s=prnb1\&issue=2006_1

2. Granitskaya, A. S. (1991), Teaching, thinking, acting : an adaptive system for school education [Nauchit' dumat' $i$ deystvovat' : adaptivnaya sistema obucheniya $v$ shkole], Prosveshcheniye, Moscow, $175 \mathrm{p}$.

3. Esipov, B. P. (1991), Independent work of students in the classroom [Samostoyatel'naya rabota uchashchykhsya na urokakh], Vysshaya shkola, Moscow, $315 \mathrm{p}$.

4. Common European framework of reference for languages: learning, teaching, assessment (2003) [Zahalnoievropeiski rekomendatsii z movnoi osvity : vyvchennia, vykladannia, otsiniuvannia], Lenvit, Kyiv, $125 \mathrm{p}$.

5 . Komensky, Ya. A. (1982), Selected pedagogical works : in 2 vol. [Izbrannyye pedagogicheskiye sochineniya: $v 2 t$.], Pedagogika, Moscow, vol. 1, 320 p.

6. Konysheva, A. V. (2003), "The group teaching technique in organizing students' independent work by the methodology", New technologies in the modern learning process [ "Gruppovoy metod obucheniya pri organizatsii samostoyatel'noy raboty studentov po metodike», Novyye tekhnologii v sovremennom protsesse obucheniya], Polotsk State University, Novopolotsk, pp. 324-329.

7. Luria, A. R. (1975), Attention and memory [Vnimaniye i pamyat'], Publishing House of Moscow State University, Moscow, 268 p.

8. Moiseienko, N. H., Sizova, L. V. (2019), Business language : a textbook [Dilova mova : navchalno-metodychnyi posibnyk], Publishing House of Odessa I. I. Mechnikov National University, Odessa, 123 p.

9. Nilson, O. A. (1986), Study of the role of students' independent work in the educational process [Issledovaniye roli samostoyatel'noy raboty uchashchikhsya v uchebnom protsesse], Valgus, Tallinn, $302 \mathrm{p}$.

10. Onuchak, L. V. (2002), Pedagogical conditions of organization of independent out-of-class work of students of economic specialties : Author's thesis [Pedahohichni umovy orhanizatsii samostiinoi pozaaudytornoi roboty studentiv ekonomichnykh spetsialnostei : avtoref. dys. ... kand. ped. nauk : 13.00.04], Kyiv, 18 p. 
МоЙСЕЕНКо Наталия Григорьевна,

кандидат филологических наук, доцент, доцент кафедры грамматики английского языка, Одесский национальный университет имени И. И. Мечникова; Французский бульвар, 24/26, г. Одесса, 65058, Украина; тел.: 067 1087618; e-mail: natalymoiswx@gmail.com; ORCID ID: 0000-0002-8465-5519

\section{СИЗоВА Любовь Владимировна,}

ст. преподаватель кафедры языковой и общегуманитарной подготовки иностранцев, Одесский национальный университет имени И. И. Мечникова; пер. Маяковского, 7, г. Одесса, 65082, Украина, тел.: +38 0671682265 ; e-mail: natalymoiswx@gmail.com; ORCID ID: 0000-0002-4849-5044

\section{САМОСТОЯТЕЛЬНАЯ РАБОТА СТУДЕНТОВ В ПРОЦЕССЕ ПРЕПОДАВАНИЯ ДЕЛОВОГО УКРАИНСКОГО И РУССКОГО ЯЗЫКОВ КАК ИНОСТРАННЫХ СТУДЕНТАМ ГУМАНИТАРНЫХ СПЕЦИАЛЬНОСТЕЙ}

Аннотация. Объект данного исследования составляют результаты наблюдений за выполнением самостоятельной работы студентами 3-4 курсов гуманитарных специальностей в процессе изучения делового украинского и русского языков как иностранных. Предмет нашего исследования - особенности организации самостоятельной работы в процессе преподавания украинского и русского делового языка как иностранного студентам 3-4 курсов гуманитарных специальностей. Цель данной статьи - анализ имеющегося опыта по организации указанного процесса и разработка алгоритма организации и контроля самостоятельной работы в процессе преподавания делового украинского и русского языков как иностранных студентам 3-4 курсов гуманитарных специальностей. Методологически представленное исследование базируется на методах анкетирования, наблюдения, сопоставления, синтеза и анализа, использована процедура описательного метода в лингвистике. Результатом исследования является алгоритм самостоятельной работы для курса делового украинского и русского языков как иностранных для студентов 3-4 курсов гуманитарных специальностей. Выводы. Самостоятельная работа студентов в процессе изучения делового украинского и русского языков как иностранных даёт возможность оптимизировать и интенсифицировать процесс обучения и сформировать у студентов навыки креативной деятельности. Самостоятельная работа студентов должна рассматриваться не как второстепенное дополнение к учебно-воспитательному процессу, а как его неотъемлемая часть. Она должна охватывать не менее $1 / 3$ количества часов, отведённых на изучение одного модуля. Важной чертой самостоятельной работы является её связь с активной и практической деятельностью, при её осуществлении необходимо применять технические средства, аудио и видео методы презентации материала, интернет.

Ключевые слова: деловой язык, креативная деятельность, самостоятельная работа, продуктивная деятельность, компетентность, украинский и русский языки.

\section{Natalia H. MOISEIENKO,}

PhD, Candidate of Science in Philology, Associate Professor, lecturer at the Department of English Grammar, Odessa National I. I. Mechnikov University; 24/26 Francuzkyi blvd., Odessa, 65058, Ukraine; tel.: +38 0671087618; e-mail: natalymoiswx@gmail.com; ORCID ID: 0000-0002-8465-5519

\section{Lubov V. SIZOVA,}

Senior lecturer at the Department of Linguistic and Humanities Training for International Students, Odessa

I. I. Mechnikov National University; 7 Mayakovskogo by-street, Odessa, 65082, Ukraine; tel.: +38 0671682265; e-mail: natalymoiswx@gmail.com; ORCID ID: 0000-0002-4849-5044

\section{STUDENTS' INDEPENDENT WORK IN THE COURSE OF TEACHING OF BUSINESS UKRAINIAN AND RUSSIAN AS FOREIGN LANGUAGES TO HUMANITIES STUDENTS}

Summary. The object of this research are the results of work with seniour humanities students in the course of teaching business Ukrainian and Russian as foreign languages to them. The subject of this scientific investigation - peculiarities of independent work organization in the process of teaching of business Ukrainian and Russian as foreign languages to seniour humanities students. The purpose of this work is to analyse the gained organizational experience of the process of teaching of business Ukrainian and Russian as a foreign language to seniour humanities students and working out of the algorithm of the independent work organization for this subject. Methodologically this research is based on the methods of questionnaire surveys, observation, comparison, synthesis and analysis, descriptive technique in linguistics. The findings of this work include the algorithm of the independent work organization for teaching of business Ukrainian and Russian as foreign languages to seniour humanities students. Results. Students' independent work in the course of study of business Ukrainian and Russian as foreign languages gives an opportunity to intensify the educational process and to develop students' creativity, this kind of work cannot be seen as some additional activity in the educational process, it deserves to be considered its integral part. It must embrace not less than $1 / 3$ of the whole number of hours assigned for one module. The most important feature of independent work is its connection with practical activity, which must be carried out with the help of technical means, audio and video programmes, the Internet.

Key words: business language, creative work, independent work, productive activity, competence, the Ukrainian and the Russian languages. 